Proceedings of SALT 24: 555-576, 2014

\title{
Is 'more possible' more possible in German?*
}

\author{
Elena Herburger \\ Georgetown University
}

\author{
Aynat Rubinstein \\ The Hebrew University of Jerusalem
}

\begin{abstract}
While some modals are clearly gradable (e.g., likely), the gradablity of possibility modals is controversial. We argue that one of the major reasons to think that possibility modals can be graded, namely the appearance of German möglich 'possible' and kann 'can' in a comparative construction involving eher, should be rethought. We argue that eher is not a simple comparative marker and propose an analysis of eher möglich in which degrees of epistemic commitment are compared, not degrees of possibility.
\end{abstract}

Keywords: Modality, gradability, comparatives, epistemic predicates, German

\section{The debate on gradable possibility}

The question of whether, or to what extent, modal predicates exhibit features of GRADABILITY has received considerable attention in the recent literature on modality. The modals in (1) are indisputably gradable: they are grammatical in comparatives and equatives, degree questions, and other degree constructions. Gradable modals span a wide range of modality types. They include epistemic-circumstantial modals such as likely, probable and chance, as well as priority modals (e.g., desirable, important as in (1a)) and ability modals (for example, capable of in (1b)). ${ }^{1}$

(1) a. It is more desirable to have some form of socialized medicine than a system of medical care relying on the private sector. ${ }^{2}$

b. He demonstrates that museums, their contents, and their manners of display

* For helpful comments and discussion, we would like to thank Paul Portner and members of the audience at SALT 24 and WCCFL 32, in particular Rajesh Bhatt, Sabine Iatridou, Peter Klecha, Dan Lassiter, Timothy Leffel, Roumyana Pancheva, Jessica Rett, Barry Schein, Florian Schwarz and Anna Szabolcsi. We gratefully acknowledge support by NSF grant BCS-1053038 "The Semantics of Gradable Modal Expressions" and the Mandel Scholion Interdisciplinary Research Center.

1 In referring to modality types (or "flavors") below, we follow Portner's (2009) terminology. Priority modality encompasses possibilities and necessities that relate to some priority, subsuming modalities that derive from the law (deontics), from desires (bouletics), and from goals (teleologicals).

2 http://gmatclub.com/forum/it-is-more-desirable-to-have-some-form-of-socialized-85302.html, accessed June 17, 2014.

C2014 Herburger and Rubinstein 
are as capable of influencing visitors as speeches or advertisements ... ${ }^{3}$

c. How likely is a young man in the U.S. to be incarcerated?

d. Somewhat/rather/highly probable.

Since gradable modal adjectives have the grammatical footprint of ordinary non-modal adjectives, their properties have recently been discussed within a more general theory of adjective meaning (Portner 2009; Yalcin 2010; Lassiter 2010, 2011; Klecha 2012; Portner \& Rubinstein to appear). This work has primarily been carried out assuming a degree-based classification of scale types, following Kennedy (1997); Rotstein \& Winter (2004); Kennedy \& McNally (2005); Kennedy (2007). ${ }^{4}$ Focusing on the epistemic-circumstantial triplet certain-likely-possible, researchers tend to agree on the classification of likely as a RELATIVE adjective, similar to big or tall. Certain, in contrast, seems to have more in common with (maximum-standard) ABSOLUTE adjectives like full (see Kennedy \& McNally 2005) and in some ways behaves like an EXTREME adjective (Portner \& Rubinstein to appear). (See Lassiter 2011 and Klecha 2012 for details of applying the scalar diagnostics to modal adjectives.)

What about possibility modals? In Kratzer's $(1981$; 1991) work, gradability is taken to be a characteristic property of modal words, including possibility modals. Kratzer observes that the noun possibility, in particular, can be modified by degree modifiers like good and slight and provides definitions for notions like good possibility that —although not compositional—derive the entailment relations between a number of related expressions of possibility (e.g., the entailment from (2a) to (2c) and from (2b) to (2c); Kratzer 1991: 645).

(2) a. There is a good possibility that Michl is the murderer.

b. There is a slight possibility that Michl is the murderer.

c. Michl might be the murderer.

As far as modal adjectives are concerned, entailment relations and scalar implicatures between certain, likely, and possible, summarized in (3), have motivated a uniform treatment of all members of this family as gradable predicates that measure degrees on the same scale (Lassiter 2010, 2011). ${ }^{5}$ It is worth noting, however, that

$3 \mathrm{http}: / /$ www.cambridgescholars.com/american-museums-and-the-persuasive-impulse-16, accessed June 17, 2014.

4 We remain non-committal with respect to whether degrees are to be thought of as numbers (a natural approach if one identifies likelihood with the scale of probability; see Portner 2009: 75) or as equivalence classes of other types of objects (Kamp 1975; Cresswell 1977; Klein 1980).

5 Lassiter (2011) interprets the fact that all three modal adjectives accept proportional degree modifiers, as in (ia), as further evidence that they are scale-mates. He proposes that this scale is the scale of probability: a ratio scale that is both lower and upper bound. Klecha (2012) challenges this conclusion 
'More possible' in German

"co-scalarity" is just one way of framing an explanation of these patterns, and that alternative approaches have been pursued (a hybrid scalar-quantificational approach is one such option; see Yalcin 2010; Klecha 2012).

(3) a. It is certain that $q$ entails It is likely that $q$ entails It is possible that $q$.

b. It is possible that $q$ implicates It is not likely/certain that $q$.

Data pertaining directly to possible, specifically to the question of whether or not it is a gradable predicate, has been a topic of debate. Lassiter (2011) maintains that possible is gradable in English, providing examples like (4).

(4) It is possible that the Jets will win, but it could be more possible. (Lassiter 2011)

He notes, however, that some speakers "express discomfort" with more possible is such examples, "preferring more likely even for small values" (ibid.). Klecha (2012) capitalizes on this judgment of discomfort to deny that possible is gradable in the first place. He reports the pattern of judgments in (5a), complementing Portner's judgments in (5b). Possible appears to be degraded in the comparative and with other degree modifiers. It is compatible with modifiers like quite and entirely/completely, but only in what are arguably non-gradable uses of these modifiers. ${ }^{6}$

a. It is $*^{*}$ more $/ *_{\text {very }} / *^{*} \mathrm{so} / *^{*}$ too $/{ }^{\mathrm{OK}}$ quite/*rather possible that the ball is in his left hand. (Klecha 2012)

b. It is *extremely/?more/entirely/completely possible that ... (Portner 2009)

Klecha (2012) supports the intuition that possible is marginal in degree constructions with a corpus study. He finds that only $0.18 \%$ of uses of possible appear with more/-er in the spoken section of the Corpus of Contemporary American English (Davies 2008-). This low rate is comparable to the average rate $(0.15 \%)$ in which non-gradable adjectives (e.g., pregnant, American, right) appear in this construction

by pointing out that $n \%$ is the only proportional modifier that is acceptable with all three modals. Other proportional modifiers, such as half (way) or three quarters, are degraded as modifiers of the epistemic trio (ib).

(i) a. It is $85 \%$ possible/likely/certain that it will rain tomorrow.

b. It is half *possible/*likely/?certain that it will rain tomorrow.

Similarly, ratio modifiers like twice as seem possible only with likely although they are predicted to occur with any gradable predicate that is associated with a ratio scale (It is twice as *possible/*certain that it will rain today as it is that it will snow).

6 See Lassiter (2011: §3.4.3.2), Klecha (2012: §2.1) for discussion. 
in the corpus. ${ }^{7}$ It contrasts sharply with the rates observed with gradable adjectives, both non-modal (9\% on average for big, small, tall etc.) and modal (18\% for likely). ${ }^{8}$

In sum, it seems that while there may be theoretical considerations that would make it appealing to posit a gradable possible, empirical data in English do not lend strong support to this view.

\section{Puzzle: German eher with possibility modals}

Of course, the relative ungrammaticality of more possible may be idiosyncratic to English. Indeed, Kratzer $(1981,2012)$ uses data from German to suggest that possibility modals are gradable in this language. Möglich 'possible' and kann 'can' are grammatical in the following comparative construction:

(6) Der Gauzner-Michl kann eher der Mörder sein als der Kastenjakl. The Gauzner-Michl can EHER the murderer be than the Kastenjakl 'Gauzner-Michl is more likely to be the murderer than Kastenjakl.' (Kratzer 1981: 297)

(7) Dies ist auf regional/lokaler Ebene eher möglich als auf der staatlichen This is on regional/local level EHER possible than on the national Ebene.

level

'It's more likely that this is possible on a regional than on a national level.' ${ }^{9}$

While Kratzer's original gloss of (6) and the similar gloss we gave for (7) support the view that the limited availability of English more possible is merely an uninteresting gap, we will argue that these glosses are not quite accurate and that a careful look at the semantic contribution of eher reveals that it is not a simple comparative morpheme, and that, as a result, the co-occurrence of eher with möglich does not provide an argument that this modal is gradable. We argue in particular that eher is semantically complex, consisting of an inferential epistemic predicate, eh-, and a clausal comparative marker -er. A more accurate (though somewhat over-explicit) gloss of (6) thus says that the speaker is more inclined to believe

7 Klecha includes dead in this class, although its status is controversial. Based on modification by almost and half, Kennedy \& McNally (2005: fn. 12) classify dead as gradable (and associated with a closed scale and an upper endpoint standard). However, it is also true that dead is clearly degraded in the comparative and that it cannot be modified by the full range of modifiers predicted by such an analysis (e.g., *slightly dead). Below, we treat German tot 'dead' as non-gradable based on its ungrammaticality in the comparative.

8 How to account for the occurrences of more possible that are nevertheless attested in the corpus would require close examination of those examples, something we will not be able to do in this paper. 9 http://www.aebr.eu/files/publications/interreg_97.de.pdf, accessed June 17, 2014. 
'More possible' in German

that Gauzner-Michl is the murderer than that Kastenjakl is. Our analysis further explains why eher creates an illusion of grading possibility when it combines with möglich/kann.

The paper is structured as follows. Section 3 discusses distributional and semantic differences between eher and the ordinary comparative -er. Section 4 presents our (de)compositional analysis of eher as comparing epistemic commitment. Immediate consequences of the analysis are explored in section 5. In section 6 we return to the debate on gradable possibility. Based on our analysis of eher möglich we conclude that the German construction offers no reason to treat 'possible' as a gradable predicate. A few further issues are discussed in section 7, and section 8 concludes.

\section{Differences between eher and -er}

A closer look at the German data reveals important differences between eher and -er, both in terms of their distribution and in terms of their semantic contribution. These differences cast doubt on an analysis of eher as an ordinary comparative morpheme.

\subsection{Distributional differences}

In German, comparative forms are obtained by adding - er to an adjective, irrespective of the number of syllables it has. With the addition of the suffix, the vowel in the stem may change (as in größ-er 'bigger').

\begin{tabular}{ll}
\hline Base form & Comparative form \\
\hline häufig & häufig-er 'more frequent' \\
groß & größ-er 'bigger' \\
wahrscheinlich & wahrscheinlich-er 'more probable/likely' \\
\hline
\end{tabular}

Table 1 Ordinary comparative inflection of German adjectives.

As seen in Table 1, the comparative form of the modal wahrscheinlich 'likely' is formed in this way. Strikingly, however, the ordinary comparative -er does not readily combine with möglich 'possible': the following sentence is ungrammatical, in sharp contrast to our previous example (7). ${ }^{10}$

10 A search using Google's Ngram Viewer does uncover some examples of möglicher as a comparative (followed by als 'than') but native speakers we checked with intuit a marked contrast in acceptability between eher möglich and the comparative, at least in present day German. Note in this context also that the string möglicher is perfectly grammatical as the genitive form of the adjective agreeing with 
The fact that möglich can co-occur with eher but cannot combine with the comparative morpheme -er parallels exactly the behavior of prototypical non-gradable adjectives like schwanger 'pregnant' and tot 'dead'. Non-gradable adjectives can co-occur with eher but not with the comparative suffix -er:

(9) Maria ist eher schwanger/*schwanger-er als Eva. Maria is EHER pregnant/pregnant-COMP than Eva

(With eher: 'I am more inclined to believe that Maria is pregnant than that Eva is.')

(10) Nach diesem Experiment werden (eher) die Mäuse in Gruppe 1 (eher) after this experiment will EHER the mice in group 1 EHER tot/*tot-er sein als die Mäuse in Gruppe 2.

dead/dead-er be than the mice in group 2

(With eher: 'I think it's more likely that after this experiment the mice in group 1 will be dead, rather than those in group 2.')

As the glosses indicate, eher schwanger does not mean 'more pregnant', not even in a coerced sense of 'more advanced in pregnancy'. Nor does eher tot mean 'closer to death'. To see more clearly what the combination of eher and a non-gradable adjective means, let's look at comparable phrases with gradable adjectives.

\subsection{Semantic differences}

Unlike non-gradable adjectives, gradable adjectives can appear with both -er and eher. The resulting interpretations differ in an interesting and revealing way:

(11) Eva ist größ-er als Maria.

Eva is tall-COMP than Maria

'Eva is taller than Maria.'

(12) Eva ist eher groß als Maria.

Eva is EHER tall than Maria

'I'm more inclined to think that Eva is tall than that Maria is.'

a genitive noun:

(ii) Unsere ist die beste aller möglicher Welten, ... ours is the best all.GEN possible.GEN worlds.GEN ...

'Ours is the best of all possible worlds.' (Leibniz) 
'More possible' in German

(11) only compares Eva's height to Maria's (claiming that the former exceeds the latter, i.e., Eva's height $>$ Maria's height). The sentence does not claim that Eva is tall, which is to say that Eva's height need not exceed the contextual standard of tallness. In contrast, (12) conveys that the speaker is more inclined to believe that Eva is tall than that Maria is. To the extent that his conjecture is correct (both in terms of what constitutes the relevant standard of tallness and in terms of how Eva's and Maria's heights are judged), Eva is indeed tall. Since (11) can be true without either Eva or Maria being tall simpliciter, it is felicitous to follow this sentence with a continuation 'but Eva is not tall'. Following (12) with this continuation creates an air of inconsistency regarding the speaker's commitments: he would be expressing relative confidence that Eva is tall while simultaneously asserting that she is not tall.

The interpretation of eher examples like (9) and (10), with non-gradable predicates, is derived in much the same way. The speaker here expresses greater confidence in one of two propositions, e.g., that Maria (as opposed to Eva) is pregnant, or that group 1 mice (rather than group 2 mice) will be dead after the experiment.

Support for the idea that an eher sentence compares the speaker's confidence in two propositions can be found in first person desire reports. While it is possible to say that one wants something more than something else (as with lieber below), it is bizarre to express epistemic confidence in what one's wishes are, since preference usually requires self awareness. (13) with eher is infelicitous for exactly this reason (as is '?I'm more inclined to think that I want to go to Vienna than stay in Bregenz'):

(13) Ich will lieber/\#eher nach Wien fahren als in Bregenz bleiben.

I want RATHER/EHER to Wien travel than in Bregenz stay

(With lieber: 'I prefer go to Vienna than stay in Bregenz.')

The oddity of (13) is not expected if eher and the desire predicate simply contribute the meaning 'more desirous' in this case. ${ }^{11}$

\section{Analysis: $e h+e r$}

The compatibility of eher with non-gradable predicates like 'pregnant' and the difference between eher sentences and minimally different sentences with a gradable adjective in the comparative clearly show that eher is not a simple comparative. This is not to say that the comparative plays no role in the meaning of eher, but it is only

11 We thus propose to gloss (iii) with an explicit epistemic component instead of as shown.

(iii) Jockl wollte diesen Mord eher begehen als Jackl. Jockl wanted this murder EHER commit than Jackl

'Jockl was more desirous of committing this murder than Jackl.' (Kratzer 2013: 184) 
one part of it: Eher, we propose, is semantically complex, consisting of $e h$ - and the comparative -er.

Our basic analysis of the eh- component of eher is as in (14): an epistemic predicate relating a proposition $p$ to the degree to which a certain individual $z$ is ready to believe that $p$ is true.

$$
[[e h-]]^{z}=\lambda p . \lambda d . z \text { is } d \text {-ready to believe } p
$$

In the remainder of this section, we elaborate on the main components of this analysis (i.e., individual orientation and readiness to believe in the truth of a proposition) and motivate an additional meaning component of the predicate having to do with the nature of the evidence that is the basis for the epistemic state it describes.

\subsection{Individual orientation}

The individual $z$ that is relevant for the interpretation of eher varies with linguistic context, as shown in (15). In a declarative, $z$ is typically the speaker (15a), in the complement of an attitude verb it is the attitude holder denoted by the matrix subject (15b), and in a question it is the addressee (15c).

a. Brasilien wird eher gewinnen als Costa Rica. Brazil will EHER win than Costa Rica 'I'm more inclined to think that Brazil will win than Costa Rica.'

b. Der Kommentator glaubt, dass Brasilien eher gewinnen wird als The sportscaster thinks that Brazil EHER win will than Costa Rica. Costa Rica

'The sportscaster thinks that Brazil is more likely to win than Costa Rica.'

c. Wird eher Brasilien oder Costa Rica gewinnen?

Will EHER Brazil or Costa Rica win

'Who do you think is more likely to win, Brazil or Costa Rica?'

This sensitivity of eher to a relevant individual recalls other expressions, such as the German particle of uncertainty wohl (Zimmermann 2004, 2009) and epistemic modals like might (Stephenson 2007; Hacquard 2010, among others), which are speech event-oriented in unembedded contexts and subject-oriented when embedded under attitude verbs (16). ${ }^{12}$ The switch in individual orientation in questions, from

12 Wohl and eher can also co-occur in contexts that allow eher, as in (iv) below. Intuitively, wohl serves to reinforce the speaker's hedging in these cases.

(iv) Der Kommentator glaubt, dass Brasilien wohl eher gewinnen wird als Costa Rica. The sportscaster thinks that Brazil WOHL EHER win will than Costa Rica 'The sportscaster thinks that Brazil is probably more likely to win than Costa Rica.' 
'More possible' in German

speaker to addressee, is well known from evidentials crosslinguistically (Speas \& Tenny 2003; and see the following section).

a. Piper might be unfaithful.

b. Schröder sagt, dass die SPD wohl Hilfe verdient. Schröder says that the SPD WOHL support deserves

'Schröder says that the SPD probably deserves support.' (Zimmermann 2009)

Just like with unembedded eher, where it is the speaker's confidence that is relevant, the individual holding the belief in the case of a matrix-level epistemic modal (16a) is typically the speaker (or a group including the speaker; see von Fintel \& Gillies 2008 and references therein). In the case of embedding, the speaker may have different opinions about the possibility of the embedded proposition or how certain it is. It is thus possible to modify the attitude verb in examples like (16b) with adverbs like 'mistakenly' (irrtümlicherweise) or 'with no good reason' (ohne guten Grund), which as matrix-level adverbs refer to the speaker's opinions and may be used to express the different opinions held by the speaker and the attitude holder.

Although we represent the individual as a parameter of evaluation on the interpretation function (recalling the "judge" parameter for epistemic modals in Stephenson's analysis), we believe an event-relative analysis (along the lines of Hacquard 2006, 2010 for epistemics) would also be possible. In both cases, an analysis of the orientation toward the addressee in questions would need to be filled in.

\subsection{Inference}

One important characteristic of eher is that it is inferential. The comparison expressed in (12), for example, requires deliberation or inference on the part of the speaker. If we see Eva standing next to Maria, a situation which directly allows us to tell who is taller, we cannot felicitously utter this sentence; we would use (11) instead. Eher is felicitous just in case the comparison is based on information that is less direct and less compelling. For instance, in choosing to utter (12) we might take into account that we heard that Eva plays basketball and that one of her brothers is very tall, whereas we do not have that kind of information about Maria.

By requiring that the grounds for the belief be indirect, eher recalls epistemic modals like must (von Fintel \& Gillies 2010) and inferential evidentials like $k^{\prime} a$ (Rullmann, Matthewson \& Davis 2008). As von Fintel \& Gillies discuss, a sentence

Not only does eher sometimes appear together with wohl, the two are also similar in taking scope over the question operator in questions (contrasting with epistemic modals, which scope beneath it; see Zimmermann 2009). We will leave these matters for future discussion. 
like It must be raining is only felicitous when the speaker lacks direct evidence about whether it is raining; that is, he or she does not actually see or experience the rain first-hand, but concludes that it is raining based on indirect evidence (e.g., people coming in with wet umbrellas). Though they mainly concentrate on must, von Fintel \& Gillies think that this indirectness (evidentiality) signal is carried by all epistemic modals. That $e h$ - seems to carry it as well would fit in with their predictions.

For our purposes we can say that $e h$ - presupposes that $z$ 's beliefs regarding the prejacent proposition $p$ are based on indirect evidence, where such evidence excludes direct visual, auditory or other sensory perception of $p$ on the part of $z \cdot{ }^{13}$ Following the literature on epistemic modals, we will model this requirement as a presupposition (Izvorski 1997; Rullmann et al. 2008; von Fintel \& Gillies 2010):

$[[e h-]]^{z}=\lambda p . \lambda d: z$ 's beliefs regarding $p$ are based on indirect evidence. $z$ is $d$-ready to believe $p$.

There are at least two ways to implement the indirectness requirement that accompanies the modal in this case. We may say that $e h$-is evaluated with respect to a modal base that is epistemic, as it represents $z$ 's beliefs, but only those beliefs of $z$ 's that are based on inferential evidence (see the epistemic modal base for the St'át'imcets inferential modal $k^{\prime} a$ in Rullmann et al. 2008). An alternative way of stating the indirectness requirement is to follow von Fintel \& Gillies (2010) in representing $z$ 's direct information (what they call a "kernel") and requiring that that information not directly settle the question of the prejacent. While there may be some empirical differences between these two approaches, for our purposes the choice between the two approaches can be left open.

\subsection{Degrees of readiness to believe}

We turn next to our claim that $e h$ is a gradable predicate that measures an individual's readiness to believe a proposition. How do we model degrees of confidence or readiness to believe? One way is to appeal to credence functions. Credence functions take a proposition as input and map it to a number representing how strongly an agent believes that the proposition is true in the actual world. It is standardly assumed that credence functions satisfy the axioms of probability (Pettigrew 2011). Thus, we can say that for John to assign the credence of 0.6 to the proposition that Eva is tall, John has to more strongly believe that Eva is tall than that she isn't (though not by much). We can then think of degrees of confidence as numbers on the credence scale.

Another way to model degrees of readiness to believe builds on the intuition that if a proposition follows from a small set of highly credible pieces of evidence,

13 The split between direct and indirect evidence is well-attested in languages that grammatically encode evidentiality. See for example Willet (1988), Aikhenvald (2004). 
'More possible' in German

an agent is more ready to believe it than she is to believe a proposition that only follows from a set that, in addition to the highly credible evidence includes other, less credible, evidence as well. This view on gradable modality is developed for non-epistemic modality in Portner \& Rubinstein (to appear). For epistemics, given a nested set of sets of propositions, the smallest of which might include what the agent considers to represent the most highly credible evidence, we find the propositions that are entailed by the conjunction of propositions in each set in the nested structure. Each such set of propositions is a degree on a scale of readiness-to-believe. We order these sets of propositions as follows: a degree $d_{1}$ that is based on a set $s_{1}$ in the nested structure of propositions is higher than a degree $d_{2}$ that is based on a set $s_{2}$ in the structure if and only if $s_{1} \subset s_{2}$. We then define the degree to which the agent is ready to believe a proposition $p$ as the highest degree (i.e., set of proposition) to which it belongs.

To summarize, we analyze the $e h$-component of eher as an epistemic predicate that carries an indirect (evidentiality) signal regarding its prejacent. This epistemic predicate measures the credence that a contextually relevant individual $z$ gives to the prejacent based on a contextually given body of indirect evidence.

\subsection{Putting the pieces together}

Turning to the contribution of the -er component of eher, we assume that -er in eh-er is a clausal comparative (consistent with Lechner 2001, 2004): it takes two sets of degrees as arguments, and requires the maximal degree of the second to be greater than the maximal degree of the first (von Stechow 1984).

$$
[[-e r]]=\lambda P_{<d, t>} \cdot \lambda Q_{<d, t>} \cdot \max (Q)>\max (P)
$$

The derivation of Eva ist eher gro $\beta$ als Maria ((12) above) is then as follows:

[-er [than eh- tall Maria is] [eh-Eva is tall]]

$[[\text { eh-Maria/Eva is tall }]]^{z}$ is only defined if $z$ 's beliefs regarding [[Maria/Eva is tall $\left.]\right]$ are based on indirect evidence. If defined, $[[\text { eh-Maria/Eva is tall }]]^{z}=\lambda d . z$ is $d$-ready to believe $[[$ Maria/Eva is tall $]]$

$\left.[[-e r]]^{z}([\text { than eh- } \text { all Maria is }]]^{z}\right)\left([[e h-\text { Eva is tall }]]^{z}\right)=$ $\max (\lambda d . z$ is $d$-ready to believe $[[E v a$ is tall $]])$

$>\max (\lambda d . z$ is $d$-ready to believe $[[$ Maria is tall $]])$

Suppose John does not know how tall Eva or Maria are but has heard that Eva plays basketball and that her brother is tall, and that Maria is a gymnast. Modeling readiness to believe in terms of credence, John's credence in the proposition that Eva is tall might be 0.6 , and his credence in the proposition that Maria is tall might be 0.3 . In other words, $\max (\lambda d . j$ is $d$-ready to believe $[[E v a$ is tall $]])=0.6$ (and 
$\max (\lambda d . j$ is $d$-ready to believe $[[$ Maria is tall $]])=0.3)$. Our analysis predicts that given his epistemic state John is justified in uttering Eva ist eher gro $\beta$ als Maria. ${ }^{14}$

\section{Immediate consequences}

Because eher is not a simple comparative on our analysis but rather a complex expression that compares the degree of inferential confidence in two propositions, we make several predictions about the content of these propositions.

One prediction is that the propositions that are compared in an eher sentence may include a comparative:

(22) Der Hirscher ist eher schnell-er als der Ligety als der Matt. The Hirscher is EHER fast-COMP than the Ligety than the Matt

'I am more inclined to think that Hirscher is faster than Ligety than I am inclined to think that Matt is faster than Ligety.'

Although it takes a moment to parse, (22) is grammatical and coherent. It compares how willing the speaker is to believe that Hirscher is faster than Ligety (both downhill skiiers), to how willing she is to believe that Matt can beat Ligety. On the surface, it appears that two comparative morphemes are related to one and the same predicate ('EHER faster'), but on our analysis eher does not really combine with 'fast(er)'; it compares the speaker's credence in two propositions, each of which contains the comparative. We thus explain why (22), though hard to parse, is fully grammatical and also how it differs from doubling a true comparative, which is strictly ungrammatical in German (as in English *more faster).

Similarly, because eher compares inferential confidence in propositions and is not a modifier of gradable predicates, we predict that it can also occur "on its own", without there being any gradable expression in the propositions being compared. (23), for example, where eher occurs on its own, is at least as natural as Kratzer's original example in (6) (repeated in (24) with our gloss), which contains the putatively gradable possibility modal kann:

Der Gauzner-Michl ist eher der Mörder als der Kastenjakl.

The Gauzner-Michl is EHER the murderer than the Kastenjakl

'I am more inclined to think that GM is the murderer than that $\mathrm{K}$ is.'

14 Note that in felicitous uses of the sentence, the speaker signals that he is not committed to fully believing that Eva is tall (or to fully believing that she isn't). If he did, he would effectively assign a credence of 1 (or 0) to the proposition and would simply assert (or deny) it. This also explains why eher comparatives cannot be felicitously followed by a denial of the compared clause (\#but Eva is not tall). The credence assigned to both of the compared propositions could be low, however; all that is required is that they be lower than 1 and higher than 0 and that one be bigger than the other. 
'More possible' in German

(24) Der Gauzner-Michl kann eher der Mörder sein als der Kastenjakl. The Gauzner-Michl can EHER the murderer be than the Kastenjakl 'I am more inclined to think that GM may be the murderer than that K may be the murderer.'

Naturally occurring examples in which eher occurs without an adjacent gradable expression are easy to find. The fact that eher easily occurs without a gradable predicate supports the view that it is not a simple comparative morpheme.

Finally, the epistemic content we attribute to $e h$ - explains the oddness of examples with first person attitude reports like (13); these amount to a comparison of epistemic confidence that one holds certain desires, where this epistemic comparison is only felicitous when there is no certainty and there is no direct evidence. This conflicts with the fact that one is normally directly aware of what one desires.

\section{Gradable possible?}

Let us return to our initial datum, the co-occurrence of eher with a possibility modal. On our account, when a modal of possibility (möglich, kann) appears with eher, what is compared is not possibility itself but a relevant individual's epistemic commitment to the possibility of the embedded proposition. For example, (7) has the following LF and interpretation (glossing over the presupposition of indirect evidence):

$$
\begin{aligned}
& {[- \text { er }[\text { than eh-is possible on the national level }]} \\
& \quad[\text { eh- } \text { is possible on a regional/local level }]] \\
& \max (\lambda d . z \text { is } d \text {-ready to believe }[[\text { It is possible on a regional/local level }]]) \\
& >\max (\lambda d . z \text { is } d \text {-ready to believe }[[\text { It is possible on the national level }]]))
\end{aligned}
$$

It follows that at least as far as eher is concerned, there is no reason to assume that 'possible' is a gradable modal notion. A traditional view of the modal as an existential quantifier is not refuted.

$$
[[\text { möglich/possible }]]=\lambda p \lambda w \cdot \exists v \cdot v \in A c c(w) \& p(v)
$$

Are there additional data to support the view that 'possible' is gradable? As noted above, inference patterns relating possible, likely, and certain have been taken to suggest that 'possible' expresses a low degree on an epistemic scale isomorphic with the scale of probability (e.g., if possible $p$ is true of a proposition $p$ just in case $p$ has a low degree on the scale and likely $p$ is true if $p$ has a higher degree on the same scale, it follows naturally that likely $p$ asymmetrically entails possible $p$; Lassiter 2011). A non-gradable analysis of 'possible', however, is not incompatible with these inferences. Klecha (2012) maintains a non-gradable analysis of possible 
and sketches an analysis of likely as a gradable predicate that measures propositions according to their likelihood, positing that the relevant notion of likelihood is additive and deriving the entailment relations from this assumption (if a proposition $p$ is likely there must be several possible worlds in which it is true, from which it follows that there is at least one where it is true, i.e. that it is possible). ${ }^{15}$

Two additional arguments could be advanced. The first concerns surface cooccurrence of possibility modals with a degree modifier, and the second a specific construction in German in which möglich seems to appear in superlative form.

\section{1 'Easily possible'}

Eher is not the only construction in which possibility modals are grammatical and are prima facie graded. Möglich and kann can be modified by the adverbs leicht 'easily' and gut 'good, well', as in (27) (see also Kratzer 1981: ex. (7), and comparable English expressions like may well be possible, easily possible, and good possibility).

a. Es ist gut/leicht möglich, dass Italien gewinnt. It is well/easily possible that Italy wins

'It is easily possible that Italy wins.'

b. Es kann aber auch gut/leicht sein, dass Spanien gewinnt.

It can but also well/easily be that Spain wins

'But it is also easily the case that Spain wins.'

It may be reasonable to argue, however, that 'easily' here does not grade the modal itself but some epistemic confidence on the part of the speaker that something is possible. In other words, we are suggesting that 'easily' and 'well' in this construction are not direct modifiers of the weak modals but rather epistemic predicates of some sort or modifiers of an epistemic predicate that is tacit/null in the sentence. Some support for this analysis can be derived from examples like (28) (in German, as well as the English translations), where these adverbs occur on their own in sentences that convey epistemic judgments.

(28) Das sind leicht/gut und gern sieben Meter.

That is easily/well and gladly seven meters

'That is easily seven meters.'

The fact that leicht and gut (in combination with gern) appear in epistemic judgments of this sort adds plausibility to the view that they contribute a similar epistemic sense in sentences with the weak modals möglich and kann.

15 Complications resulting from world ordering would have to be taken into account for this kind of explanation to go through, of course. 
'More possible' in German

\subsection{German superlative 'possible'}

Another construction that might be taken to suggest that möglich is gradable is shown in (29). Rather strikingly, the modal appears with a prototypical marker of gradability in this construction: superlative morphology. ${ }^{16}$

(29) Komm bitte möglich-st schnell.

Come please possible-EST quickly

'Please come as quickly as possible.'

(29) is a request of the addressee to come as quickly as is possible for her to come, i.e., to come in the quickest way possible. It expresses a meaning very similar to the construction known as the adjectival modal superlative (Corver 1997; Larson 2000; Schwarz 2005; Romero 2013). In the adjectival modal superlative in (30), the superlative morphology appears on the non-modal adjective.

(30) Komm bitte auf dem schnell.st möglich.en Weg. Come please on the fast.EST possible.DAT way

'Please come in the quickest way possible.'

In contrast, when the noun phrase is indefinite, the superlative morphology appears again on the modal, as in (31a). Since the order of möglich and the nonmodal adjective is switched in these cases, it seems reasonable to assume that the superlative morpheme simply appears on the first element of the noun phrase ('possible' in the indefinite noun phrase, 'fast' in the definite one).

a. Alle wollen eine möglich.st schnell.e Lösung. everyone wants a possible.EST fast.ACC solution 'Everyone wants a solution that is as fast as possible.'

b. Alle wollen die schnell.st möglich.e Lösung. everyone wants the fast.EST possible.ACC solution 'Everyone wants the fastest solution possible.'

Regardless of where the superlative appears, 'possible' is interpreted "nonlocally" in this construction, i.e., not as a modifier of the noun it precedes (e.g., Weg 'way' in (30)), but essentially as in (29). ${ }^{17}$

Under Romero's (2013) analysis, the modal superlative (30) is a request that the maximal degree of quickness with which the addressee come not be smaller than the

16 We thank Timothy Leffel (p.c.) for pointing out the relevance of these examples for our discussion. 17 A "local", or modifying, reading of the modal and the noun it precedes is also possible. As noted by Schwarz (2005), following Corver (1997) on Dutch, the local reading arises in German when both prenominal adjectives are inflected (größ.t.e, möglich.e below). In contrast, only the modal superlative reading is available when the superlative adjective is not inflected (größ.t and (30)): 
maximal degree of quickness with which it is possible for her to come. Although the superlative in (30) surfaces on 'fast', the two come apart in the semantics, and, crucially, 'possible' retains its ordinary, non-gradable meaning.

A different analysis is pursued by Schwarz (2005), who proposes that the superlative and 'possible' do indeed form a unit. Crucially, however, it is a primitive, non-compositional unit; [-est possible] $\phi$ is true just in case in the real world the degree property denoted by $\phi$ holds of any degree that it holds of in any of the worlds that are accessible from the real world. Since on Schwarz's analysis -est and possible are treated in a non-compositional way where neither has its normal meaning, the analysis does not really provide an argument that 'possible' is graded by -est.

Though it goes beyond the scope of this paper, if we were to extend a Romerostyle analysis to examples like (31a) and (29), where the superlative morphology surfaces on the modal adjective, we could say that, again, the superlative is clausal and that one of the clauses it takes as an argument contains 'possible' as a regular modal operator. Where the superlative surfaces seems to be a morpho-syntactic issue that leads to some non-transparency between the syntax and the semantics.

\section{Further issues}

We would like to mention two further properties of $e h$ - before concluding.

The $e h$ - we posit as forming a part of eher cannot occur unbounded as an epistemic predicate meaning 'ready to believe'. There is, however, a discourse particle $e h$ which seems quite closely related in meaning. It is typical of Austrian and Bavarian dialects but is also accessible to speakers of other dialects.

(32) Das ist auf regionaler Ebene eh möglich.

That is on regional level $\mathbf{E H}$ possible

'That is anyways possible on a regional level.'

The discourse particle $e$ h roughly translates as 'anyways' or 'obviously', invoking the relevance of some additional information. It conveys that there is no reason to doubt the prejacent and that it holds independently of the content of the conversation (Hentschel 1986). The discourse particle $e h$ and the $e h$ - component of $e h e r$ are quite similar; both describe the speaker's confidence in the truth of the prejacent and say

(v) Ich habe das größ.t/größ.t.e möglich.e Geschenk gekauft.

I have that big.EST/big.EST.DAT possible.DAT present bought

'I bought the largest present possible.' vs. 'I bought the largest of the possible presents.'

We would like to add that the option of having an uninflected superlative seems to be only possible with a limited set of adjectives, e.g., 'big', 'small', 'good', 'fast'. It certainly is not possible with every adjective (*elegantest mögliche Lösung 'most elegant solution possible', *rotest mögliche Lippenstift 'reddest lipstick possible'). 
that it is based on something indirect, either something that is not currently being talked about but is given antecedently (discourse particle) or something for which there is no direct support but only indirect evidence (epistemic part of eher).

A second notable fact about eher and the superlative am ehesten is that they can be used to express temporal, not just modal, comparison. The temporal meaning in fact predates the modal meaning, as eh(-er,-est) develop from Gothic air 'early(-ier,iest)'. The temporal meaning of eh(e), eher, ehest though somewhat old-fashioned is still available to speakers. It appears in phrases like seit eh und je 'from time immemorial' and is also compositionally available: (15a), for example, can be used to convey a prediction that Brazil will win before Costa Rica will. ${ }^{18}$

It is arguably also the temporal meaning that appears in combination with the volitional predicate in the following slightly archaic-sounding sentence.

Eher will ich sterben als ihn heiraten. EHER want I die than him.ACC marry 'I'd sooner die than marry him.'

The strong dislike expressed by (33) to marry a certain person may be attributed to the temporal reading of eher. Assuming one generally first does that which one is less disinclined to do, and that one does not want to die, then if marriage to the person in question seems even less appealing than dying, it follows that one

18 Kratzer (2013) highlights the temporal reading of eher in relation to a curious fact about what appear to be cross-scalar comparisons like (vi). While this example is ungrammatical on what we have described as an epistemic reading (hence the *), it is fully grammatical on a temporal reading of eher (to our ears, eher needs to be stressed for the sentence to be fully acceptable).

(vi) *Jockl wollte diesen Mord eher begehen als er konnte. Jockl wanted this murder EHER commit than he could

'Jockl was more desirous than capable of committing the murder.'

Kratzer leaves the ungrammaticality of the non-temporal reading as a puzzle, noting that it would seem to indicate that comparison across 'want' and 'can' is impossible here. There are other examples with 'want', 'can' and eher that seem less deviant, however. In (vii), wollen and können are stressed and eher has the epistemic reading:

(vii) weil Jockl diesen Mord eher begehen WOLLTE als begehen KONNTE. because Jockl this murder EHER commit wanted than commit could 'because I am more inclined to think that Jockl wanted to commit this murder than I am to think that he could actually commit it.'

Examples like (vii) suggest that desire and possibility are comparable when embedded under the epistemic component of eher, and that the ungrammaticality of (vi) on the epistemic interpretation might have an independent syntactic explanation. Possibly, the lack of parallelism in syntactic positions of the finite verbs in (vi) interferes with a requirement that these verbs be stressed when they form part of an epistemic eher comparison. The focus sensitivity of eher on its epistemic reading (as opposed to its temporal reading) is a topic we must leave for future research. 
certainly does not want to marry that person. It is worth noting that English sooner is similar in having both a temporal reading and a modal-like meaning expressing preference (as in I'd sooner die than marry him). Interestingly, English sooner (and rather, which historically also derives from 'earlier'), cannot be used in the epistemic sense described in this paper. Unlike eher, they are restricted in their modal uses to volitional contexts where they often appear in combination with would.

It is tempting to pursue an account that draws a connection between the temporal and modal meanings of eher. We would like to speculate about a possible connection between 'early' and 'readiness to believe', similar to the one just suggested in connection with the volitional predicate: presumably the clearer something is the less time one needs to convince oneself of its truth. We hope to explore this connection in more depth in future work.

\section{Conclusions}

In this paper, we took a close look at German eher comparatives with possibility modals which, at first sight, seem to provide compelling evidence for a gradable notion of possibility. We argued that eher is semantically complex: it includes a clausal comparative component, denoted by -er, and a gradable epistemic component, expressed by eh-. When eher appears together with a possibility modal, it does not grade that modal. Rather, it expresses a comparison between how ready a relevant individual is to believe two possibility statements. We showed that this analysis of eher also explains its appearance in sentences lacking gradable expressions. Additional constructions in which possibility modals seem to be graded, including certain cases of degree modification and different varieties of modal superlatives, were also argued not to provide evidence for gradable denotations of modals like möglich 'possible'. In sum, we conclude that there is little reason to believe that möglich is gradable in German. While the dearth of more possible examples might have been set aside as a curious gap rendered insignificant by the German data, our discussion suggests that this gap is not accidental.

Interesting aspects of the meaning of eher we discussed only briefly and hope to further develop in the future concern the evidential component of $e h-$, analyzed here as a presupposition, the relation between $e h$ - and discourse particles (wohl and the homophonous $e h$ ), and its historical roots as an expression of earliness. Another comparative construction that has been identified as not involving direct comparison, and in this respect resembles eher comparatives, is the so-called "metalinguistic comparative" (She is more a linguist than a philosopher; McCawley 1968; Lechner 2009; Morzycki 2009, 2011; Giannakidou \& Stavrou 2009; Giannakidou \& Yoon 2009, 2011). A more complete study will also elucidate how eher comparatives fit in the broader typology of comparative constructions crosslinguistically. 
'More possible' in German

\section{References}

Aikhenvald, Alexandra Y. 2004. Evidentiality. Oxford: Oxford University Press. Corver, Norbert. 1997. Much-support as a last resort. Linguistic Inquiry 28(1). 119-164.

Cresswell, Max J. 1977. The semantics of degree. In Barbara H. Partee (ed.), Montague Grammar, 261-292. NewYork: Academic Press.

Davies, Mark. 2008-. The Corpus of Contemporary American English: 450 million words, 1990-present. http://corpus.byu.edu/coca/.

von Fintel, Kai \& Anthony S. Gillies. 2008. CIA leaks. Philosophical Review 117(1). 77-98.

von Fintel, Kai \& Anthony S. Gillies. 2010. Must... stay... strong! Natural Language Semantics 18. 351-383.

Giannakidou, Anastasia \& Melita Stavrou. 2009. Metalinguistic comparatives and negation in Greek. In Claire Halpert, Jeremy Hartman \& David Hill (eds.), The 2007 workshop on Greek syntax and semantics (MIT Working Papers in Linguistics 57), 57-74. Cambridge: MIT Press.

Giannakidou, Anastasia \& Suwon Yoon. 2009. Metalinguistic functions and the expressive dimension in Greek and Korean: Attitude semantics, expressive meaning and NPI licensing. In Ljudmila Geist, Klaus von Heusinger, Hans Kamp, Udo Klein, Fabienne Martin, Edgar Onea, Arndt Riester, \& Torgrim Solstad (eds.), Sinn und Bedeutung 13, 141-156. Stuttgart: OPUS.

Giannakidou, Anastasia \& Suwon Yoon. 2011. The subjective mode of comparison. Natural Language and Linguistic Theory 29. 621-655.

Hacquard, Valentine. 2006. Aspects of Modality: Massachusetts Institute of Technology $\mathrm{PhD}$ dissertation.

Hacquard, Valentine. 2010. On the event relativity of modal auxiliaries. Natural Language Semantics 18. 79-114.

Hentschel, Elke. 1986. Funktion und Geschichte deutscher Partikeln: Ja, doch, halt und eben. Tübingen: Niemeyer.

Izvorski, Roumyana. 1997. The present perfect as an epistemic modal. In Aaron Lawson (ed.), Semantics and Linguistic Theory (SALT) VII, 222-239. Ithaca: CLC Publications.

Kamp, Hans. 1975. Two theories about adjectives. In Edward Keenan (ed.), Formal Semantics for Natural Language, 123-155. Cambridge: Cambridge University Press.

Kennedy, Christopher. 1997. Projecting the Adjective: The Syntax and Semantics of Gradability and Comparison: University of California Santa Cruz PhD dissertation.

Kennedy, Christopher. 2007. Vagueness and grammar: the semantics of relative and 
absolute gradable adjectives. Linguistics and Philosophy 30. 1-45.

Kennedy, Christopher \& Louise McNally. 2005. Scale structure, degree modification, and the semantic typology of gradable predicates. Language 81. 345-381.

Klecha, Peter. 2012. Positive and conditional semantics for gradable modals. In Ana Aguilar-Guevara, Anna Chernilovskaya \& Rick Nouwen (eds.), Sinn und Bedeutung 16, vol. 2, 363-376. Cambridge: MIT Working Papers in Linguistics.

Klein, Ewan. 1980. A semantics for positive and comparative adjectives. Linguistics and Philosophy 4. 1-45.

Kratzer, Angelika. 1981. The notional category of modality. In Hans-Jürgen Eikmeyer \& Hannes Rieser (eds.), Words, Worlds, and Contexts, 38-74. Berlin: Walter de Gruyter. Reprinted in Formal semantics: The essential readings, ed. Paul Portner and Barbara H. Partee (2002), 289-323. Oxford: Blackwell.

Kratzer, Angelika. 1991. Modality. In Arnim von Stechow \& Dieter Wunderlich (eds.), Semantik: Ein internationales Handbuch zeitgenoessischer Forschung, 639-650. Berlin: de Gruyter.

Kratzer, Angelika. 2012. Modals and Conditionals. Oxford: Oxford University Press.

Kratzer, Angelika. 2013. Modality for the $21^{\text {st }}$ century. In Stephen R. Anderson, Jacques Moeschler \& Fabienne Reboul (eds.), The Language-Cognition Interface: Actes du $19^{e}$ Congrès International des Linguistes, 179-199. Genève: Libraire Droz.

Larson, Richard. 2000. ACD in AP? Paper presented at the 19th West Coast Conference on Formal Linguistics (WCCFL), University of California Los Angeles, February 4-6.

Lassiter, Daniel. 2010. Gradable epistemic modals, probability, and scale structure. In Nan Li \& David Lutz (eds.), Semantics and Linguistic Theory (SALT) XX, 197-215. CLC Publications.

Lassiter, Daniel. 2011. Measurement and modality: The scalar basis of modal semantics: New York University PhD dissertation. November 2011.

Lechner, Winfried. 2001. Reduced and phrasal comparatives. Natural Language and Linguistic Theory 19(4). 683-735.

Lechner, Winfried. 2004. Ellipsis in Comparatives. Berlin: Mouton de Gruyter.

Lechner, Winfried. 2009. Metacomparatives: Comments on 'Metalinguistic contrast in the grammar of Greek' by Giannakidou \& Stavrou. In Claire Halpert, Jeremy Hartman \& David Hill (eds.), The 2007 workshop on Greek syntax and semantics (MIT Working Papers in Linguistics 57), 75-91. Cambridge: MIT Press.

McCawley, James D. 1968. The role of semantics in a grammar. In Emmon Bach \& Richard Harms (eds.), Universals in Linguistic Theory, 124-169. New York: Holt, Rinehart, and Winston.

Morzycki, Marcin. 2009. Metalinguistic comparison in an alternative semantics for 
'More possible' in German

imprecision. In Muhammad Abdurrahman, Anisa Schardl \& Martin Walkow (eds.), The North East Linguistic Society (NELS) 38, vol. 2, 149-164. Amherst: GLSA.

Morzycki, Marcin. 2011. Metalinguistic comparison in an alternative semantics for imprecision. Natural Language Semantics 19. 39-86.

Pettigrew, Richard. 2011. Epistemic utility arguments for probabilism. In Edward N. Zalta (ed.), The Stanford Encyclopedia of Philosophy, Winter 2011 edn.

Portner, Paul. 2009. Modality Oxford surveys in semantics and pragmatics. Oxford: Oxford University Press.

Portner, Paul \& Aynat Rubinstein. to appear. Extreme and non-extreme deontic modals. In Nate Charlow \& Matthew Chrisman (eds.), Deontic Modality, Oxford University Press.

Romero, Maribel. 2013. Modal superlatives: a compositional analysis. Natural Language Semantics 21. 79-110.

Rotstein, Carmen \& Yoad Winter. 2004. Total adjectives vs. partial adjectives: Scale structure and higher-order modifiers. Natural Language Semantics 12(3). 259-288.

Rullmann, Hotze, Lisa Matthewson \& Henry Davis. 2008. Modals as distributive indefinites. Natural Language Semantics 16. 317-357.

Schwarz, Bernhard. 2005. Modal superlatives. In Efthymia Georgala \& Jonathan Howell (eds.), Semantics and Linguistic Theory (SALT) XV, 187-204. Ithaca: CLC Publications.

Speas, Peggy \& Carol Tenny. 2003. Configurational properties of point of view roles. In Anna Maria Di Sciullo (ed.), Asymmetry in Grammar, vol. 1: Syntax and Semantics, 315-344. John Benjamins.

von Stechow, Arnim. 1984. Comparing semantic theories of comparison. Journal of Semantics 3. 1-77.

Stephenson, Tamina. 2007. Judge dependence, epistemic modals, and predicates of personal taste. Linguistics and Philosophy 30. 487-525.

Willet, Thomas. 1988. A cross-linguistic survey of the grammaticalization of evidentiality. Studies in Language 12(1). 51-97.

Yalcin, Seth. 2010. Probability operators. Philosophy Compass 5(11). 916-937.

Zimmermann, Malte. 2004. Zum "wohl”: Diskurspartikeln als Satztypmodifikatoren. Linguistische Berichte 199. 1-35.

Zimmermann, Malte. 2009. Discourse particles in the left periphery. In Benjamin Shaer, Philippa Cook, Werner Frey \& Claudia Maienborn (eds.), Dislocated Elements in Discourse Routledge Studies in Germanic Linguistics, 200-231. New York: Routledge. 
Herburger and Rubinstein

Elena Herburger

Department of Spanish and Portuguese Georgetown University

Washington, DC 20057 USA

herburge@georgetown.edu
Aynat Rubinstein

The Mandel Scholion Interdisciplinary Research Center in the Humanities and Jewish Studies

The Hebrew University of Jerusalem

Jersualem, 91905 Israel

aynat.rubinstein@mail.huji.ac.il 